\title{
Qualitative Cost-Benefit Analysis of Using Pesticidal Plants in Smallholder Crop Protection
}

\author{
Angela G. Mkindi ${ }^{1, *}$, Richard Coe ${ }^{2,3}$, Philip C. Stevenson ${ }^{4,5}{ }^{\circledR}$, Patrick A. Ndakidemi ${ }^{1}$ and Steven R. Belmain ${ }^{5}$ \\ 1 Department of Sustainable Agriculture, Biodiversity and Ecosystems Management, The Nelson Mandela \\ African Institution of Science and Technology, Arusha P.O. Box 447, Tanzania; \\ patrick.ndakidemi@nm-aist.ac.tz \\ 2 World Agroforestry Centre, Nairobi 00100, Kenya; r.coe@cgiar.org or r.coe@stats4sd.org \\ 3 Statistics for Sustainable Development, Reading RG1 4QS, UK \\ 4 Royal Botanic Gardens, Kew, Richmond, Surrey TW9 3DS, UK; P.Stevenson@kew.org \\ 5 Natural Resources Institute, University of Greenwich, Central Avenue, Chatham Maritime, \\ Kent ME4 4TB, UK; S.R.Belmain@greenwich.ac.uk \\ * Correspondence: angela.mkindi@nm-aist.ac.tz
}

Citation: Mkindi, A.G.; Coe, R.; Stevenson, P.C.; Ndakidemi, P.A.; Belmain, S.R. Qualitative Cost-Benefit Analysis of Using Pesticidal Plants in Smallholder Crop Protection. Agriculture 2021, 11, 1007. https:// doi.org/10.3390/agriculture11101007

Academic Editor: Oscar E. Liburd

Received: 20 September 2021

Accepted: 12 October 2021

Published: 15 October 2021

Publisher's Note: MDPI stays neutral with regard to jurisdictional claims in published maps and institutional affiliations.

Copyright: (c) 2021 by the authors. Licensee MDPI, Basel, Switzerland. This article is an open access article distributed under the terms and conditions of the Creative Commons Attribution (CC BY) license (https:// creativecommons.org/licenses/by/ $4.0 /)$.

\begin{abstract}
Assessing the potential drivers of farmers using pesticidal plants for crop protection is essential for wider adoption. However, few studies have focused on collaborative assessments of the underlying trade-offs when using pesticidal plant extracts for pest control. Smallholder farmers in northern Tanzania involved in farmer driven research assessing pesticidal plants evaluated the costs, benefits, trade-offs and areas for future investment. A questionnaire was used to collect demographic information from 77 farmers and their views on pest problems and crop protection in common bean production. This was followed by small focus group discussions $(n=9)$ using a participatory framework to elucidate the costs and benefits of adopting pesticidal plant technology. A multiple correspondence analysis showed that pesticidal plant use was associated with men greater than 50 years old, and synthetic pesticide use was associated with younger aged farmers and women. Farmers who used synthetics generally did not report the presence of common pest species found in common bean production, whereas farmers who used pesticidal plants were associated with more frequent reports of pest species. This participatory cost-benefit analysis highlighted that tools and processing challenges were the main costs to using pesticidal plants. The main benefit reported when using pesticidal plants was a general improvement to family health. Farmers expressed overall a positive outcome when using pesticidal plants for crop protection and recommended that future investments focus on improving access to tools and education regarding plant processing and extraction to improve uptake of the technology by smallholder farmers.
\end{abstract}

Keywords: pesticidal plants; smallholder farmers; Phaseolus vulgaris; pest management; qualitative cost benefit analysis

\section{Introduction}

Crop pest management using pesticidal plants has been practiced for hundreds of years [1]. Commercialised pesticidal plant products derived from neem (Azadirachta indica) and pyrethrum (Tanacetum cinerariifolium) are the most widely used in crop protection, particularly in large-scale agricultural systems, although a small number of farmers still handle pest management with synthetic pesticides [2]. The greatest opportunities for the use of pesticidal plants are arguably among smallholder farmers, as they have access within their local environments to many plant species with known efficacy [3]. Nevertheless, in smallholder farming contexts, the use of pesticidal plants is often limited, despite great scope for widescale adoption [4]. We propose that support for pesticidal plant use within resource-poor smallholder farming communities is challenged by inadequate information about the underlying drivers of use. Carrying out participatory cost-benefit analyses may 
help to highlight essential information that enable rigorous designing of strategies for successful adoption. Moreover, an elucidation of costs and benefits by farmers may lead to better understanding of farmer behaviour and perception towards pesticidal plants use in addition to widely accept monetary-based cost-benefit ratios that influence the sustainable use of pesticidal plants.

A cost benefit analysis of agricultural technology or 'option' is used to evaluate the inputs or investments (the costs) worth making given outputs or returns (benefits) [5]. The analysis is often done to compare one or new technologies with some current practices. Most analyses of costs and benefits requires the use of monetary values on the inputs and outputs to provide benefits based on calculated differences [6]. Indices of the results include cost-benefit ratio, net present value, internal rate of return and returns to land or labour [7]. However, social involvement is one of the key aspects of food production such that understanding of diverse ideas based on collaborative discussions is required to reflect cost-benefit dynamics. The conventional cost-benefit analysis relying on monetary values may be difficult or impossible to assess and relate to actual contexts such as smallholder behaviours. Likewise, non-monetary costs and benefits provide context-based information as opposed to financial gain. In that perspective, ideas of the costs, benefits and possible social concerns that may change the balance from costs to benefits need to be considered more broadly than standard cost-benefit analyses procedures. A participatory and (semi) qualitative method that avails social costs, benefits, balances and options is used in this study. Factors discussed are not transformed into monetary values, and the balance is decided by participatory discussion rather than by applying a formula. This study, therefore, augments the standard cost-benefit analyses by connoting the cost-effectiveness of crop protection treatments.

Decades of scientific research evidence support the effective protection of crops using pesticidal plants $[3,8]$. In comparison to synthetic pesticides, advantages of using pesticidal plants include their lower persistence in the environment, reduced impacts on non-target organisms including humans and reduced development of pest resistance [9]. Multiple benefits from pesticidal plants favour smallholder farming communities who can produce pesticidal sprays from local resources, often using multi-purpose plant species that may help pollinators and natural enemies [10,11], improve soil fertility $[12,13]$ and act as foliar fertilisers [14] or green mulch [15,16], whilst avoiding associated costs from purchasing expensive synthetic products, and related issues such as adulterated or counterfeited products and application illiteracy [17]. Smallholder farmers involved in this study had used pesticidal plants for over three years. Since 2013, a research program has been undertaken to reinvigorate the use of pesticidal plants and involve farmers in the optimization of plant extraction and application through a farmer research network (FRN). Early studies focussed on efficacy $[18,19]$, and these were followed by more participation by farmers and the development of a farmer research network (FRN) in 2016 (Figure 1). The FRN is a large-scale participatory approach that enables farmer research participation and empowerment [20]. Through the FRN approach, wider participation and perspectives need to inform adoption strategies. Hence, appropriate data on factors that can influence smallholder farmers' uptake of pesticidal plants could inform efforts toward promoting the technology. 


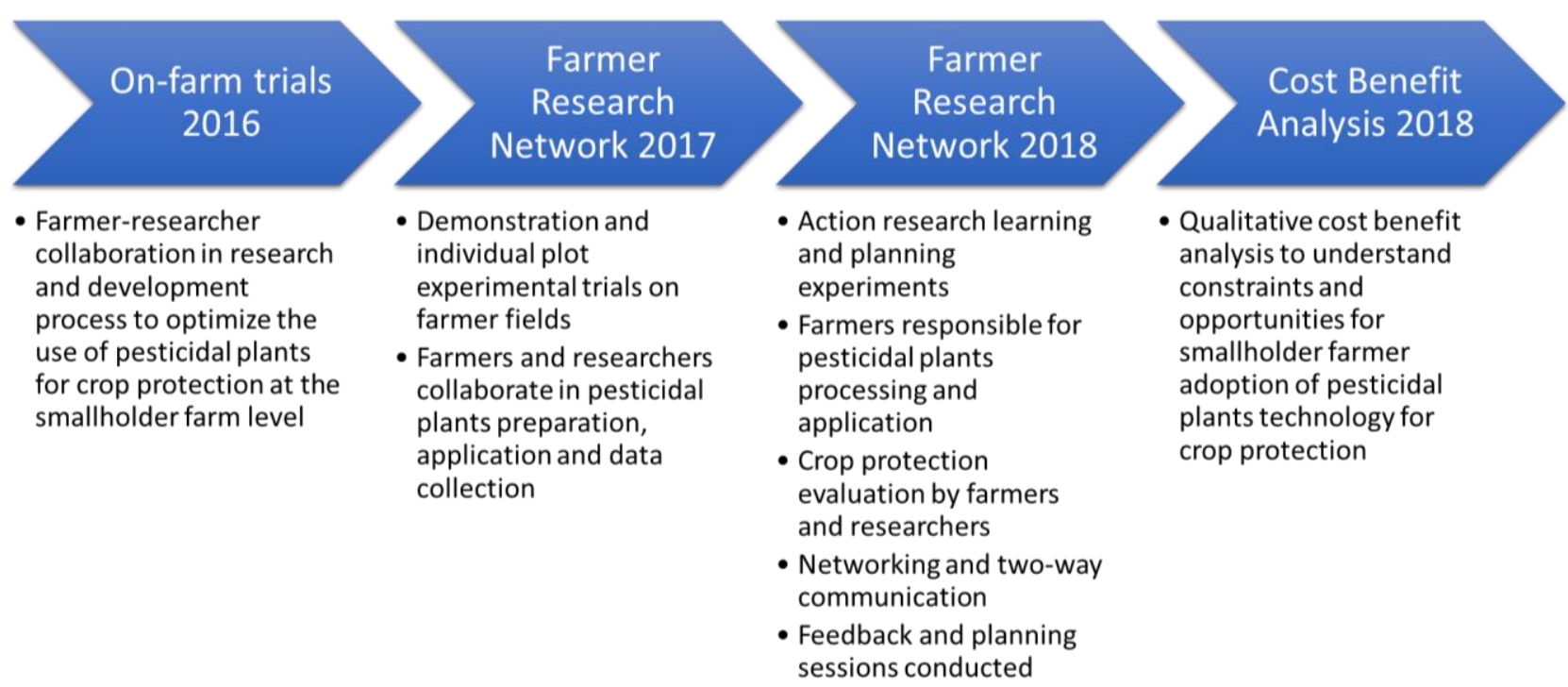

Figure 1. The impact pathway of farmer participation in evaluating pesticidal plants for common bean pest management.

\section{Materials and Methods}

\subsection{Study Area}

The study was in Mulama village, Hai district, Kilimanjaro region, Tanzania (Latitude $3^{\circ} 13^{\prime} 59.59^{\prime \prime} \mathrm{S}$ Longitude $37^{\circ} 14^{\prime} 54^{\prime \prime} \mathrm{E}$ ). The study area is located at an altitude of $1268 \mathrm{~m}$ above sea level with the mean annual rainfall of $1200 \mathrm{~mm}$ and a mean annual temperature of $18{ }^{\circ} \mathrm{C}$. Major crops grown in this area include common beans, maize, banana and coffee. Common beans and maize are widely grown as subsistence crops and often replace coffee plantations where production is deteriorating. The primary constraint in common bean and maize production in the region has been insect pests, and most farmers use synthetic pesticides heavily due to high insect pest numbers present particularly in large monocropped areas. The current study involved farmers who participated in the implementation of the FRN for two consecutive years (2017 and 2018) in addition to their involvement into the first year of on-farm trials. This network enabled farmers to participate in growing, harvesting, processing and applying pesticidal plants for crop protection, particularly collaborative experimentation and evaluation of the efficacy of plant extracts on pests of common beans. Information reported in this study consists of data collected within a survey on farmers' perceptions and experiences about using pesticidal plants in common bean fields. Our expectation is that such farmers will be able to bring insights on how to increase the adoption of pesticidal plants from their own learning and experiences.

\subsection{Survey Questionaire and Cost Benefit Analysis}

Ethical clearance to carry out individual questionnaires and group discussions was granted by the ethics committee of Nelson Mandela African Institution of Science and Technology. Demographic information was obtained through a questionnaire (see Supplementary Materials S1) that interviewed 77 individual farmers. Questions aimed to collect data on socio-economic status of farmers and their experience on sustainable insect pest control through using pesticidal plants. Consent for participation in the survey was sought from local officials with approval granted from the agricultural officers in the district, ward and village authorities before seeking involvement and permission from farmers through signed consent forms. The study was conducted from October 2017 to January 2018 covering four cropping seasons. Data collection was done using smart phones and the Kobo Toolbox application (Questionnaire survey. Available online: https: / / www.kobotoolbox.org/ (accessed on: 14 January 2019)) in collaboration with trained research assistants. 
Focus groups discussions (FGD) were carried out with a total of 81 participants across 9 separate groups, which aimed at exploring costs, benefits, trade-offs and future investments for using pesticidal plants for pest management. Focus groups were based on pre-existing local groups of farmers who practiced pest management using pesticidal plants over the past two years, and participants in the FGD consisted of the same farmers involved in the individual questionnaire survey with the inclusion of four more farmers who could not participate in the questionnaire survey. Discussion focused on defining benefits and costs and then prioritising them. This was followed by discussing future options and contextual situations that could potentially influence costs and benefits of using pesticidal plants (Figure 2 and Supplementary Materials S2). The FGDs took place in January 2018, and group meetings took approximately two hours each, with audio recording to extract and codify information collected. All participants signed consent forms for involvement in the discussion.

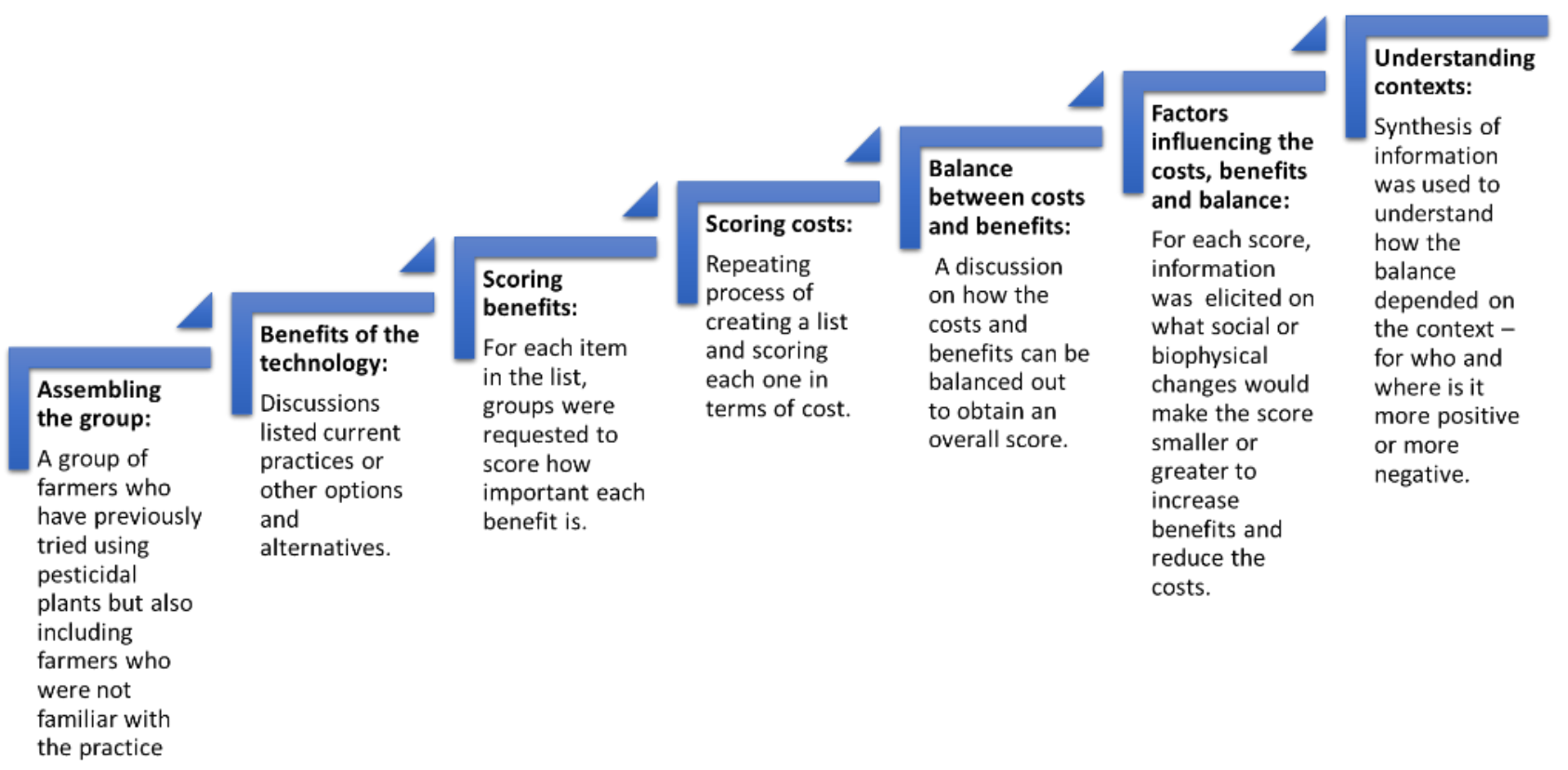

Figure 2. The steps involved in qualitative cost-benefit analysis.

\subsection{Data Processing and Analysis}

Questionnaire data were analysed for correlations using a Spearman similarity matrix to look for significant correlations, followed by a multiple correspondence analysis to investigate potential relationships between respondent age and gender together with their answers to questions on pesticidal plants use and insect pests. Analyses were carried out in Xlstat version 17.01 (Addinsoft, Paris, France). Written notes and audio recordings were transcribed, first in Kiswahili and then to English. Coding of crucial information was used to discuss the factors that affect or influence farmers' adoption and use of pesticidal plants.

\section{Results}

\subsection{Participant Demographics and Pest Control}

Participants in the study included more female than male participants, and most participants were above 50 years old (Table 1). Most households consisted of five or fewer family members, with larger families being uncommon. A high percentage of farmers were literate. More than $90 \%$ had attended primary school, and only 3\% reported no school attendance. Approximately three quarters of farmers practised intercropping. Beans were mostly intercropped with maize. Land ownership where common beans were planted varied. The majority $(61.8 \%)$ were cultivated on rented fields (Table 1$)$. Rented fields were generally further away from communities where large cropping areas could be found that 
were favourable for maize/bean intercropping. Family farms were generally close to the family houses and often contained mixed cropping with coffee and bananas.

Table 1. Demographic data from survey participants. Each number is a percentage of respondents, which is followed by the number of respondents in brackets.

\begin{tabular}{cc}
\hline Respondent Demographics & Percentage (Number) \\
\hline Education level & \\
Did not attend school & $2.9(2)$ \\
Primary education & $91.2(62)$ \\
Secondary education & $4.4(3)$ \\
Higher education & $1.5(1)$ \\
Age & \\
$20-30$ & $10.3(7)$ \\
$31-40$ & $4.4(3)$ \\
$41-50$ & $26.5(18)$ \\
$>50$ & $58.8(40)$ \\
Family size & \\
$1-5$ & $92.6(63)$ \\
6-10 & $7.4(5)$ \\
Gender & \\
Male & $41.2(28)$ \\
Female & $58.8(40)$ \\
Land ownership & $36.8(25)$ \\
Family farm & $1.5(1)$ \\
Bought & $61.8(42)$ \\
Rented & $23.5(16)$ \\
Cropping system & $76.5(52)$ \\
Monocrop & \\
Intercrop &
\end{tabular}

\subsection{Perceptions on Pests and Pest Control Practices}

Nearly all farmers participating in the study reported high pest incidences and acknowledged pests as a severe challenge in common bean production. A majority reported the primary bean pests to be foliage beetles (Ootheca mutabilis and O. bennigseni) and aphids (Aphis fabae); fewer reported problems with pod suckers (Clavigralla tomentosicollis, C. schadabi and C. hystricodes) and flower beetles (Epicauta albovittata and E. limbatipennis) (Table 2). Similar numbers of farmers reported that they used extracts of pesticidal plants and synthetic pesticides. Roughly $60 \%$ of farmers said they did not use any pest control products. However, use of pesticidal plants and synthetics varied according to farmer age: pesticidal plant use increased with participant age and synthetic use decreased with participant age (Figure 3). A multiple correspondence analysis was able to show further correlations in participant responses, including indicating that the use of pesticidal plants was significantly associated with males above the age of 51 , whereas the use of synthetics was associated with younger farmers and female farmers (Figure 4). The use of pesticidal plants was associated with higher reports of aphids, foliage beetles, flower beetles and pod suckers. Participants reporting the use of synthetics were associated with fewer reports of insect pests. Further MCA analyses were unable to determine significant associations between participant education, family size, land ownership and cropping system and the participants' responses. 
Table 2. Pest problems in common bean production and control strategies reported by survey participants. Each number is a percentage of respondents, which is followed by the number of respondents in brackets.

\begin{tabular}{cc}
\hline Participant Responses & Percentage (Number) \\
\hline Pest presence & \\
Aphids & $63.2(43)$ \\
Foliage beetle & $75.0(51)$ \\
Flower beetle & $26.5(18)$ \\
Pod sucker & $11.8(8)$ \\
Extension service access & \\
Yes & $25(17)$ \\
No & $75(51)$ \\
Using pesticidal plants before the project & $39.7(27)$ \\
Yes & $60.3(41)$ \\
No & $35.3(24)$ \\
Ysing synthetic pesticides before the project & $64.7(44)$ \\
No &
\end{tabular}

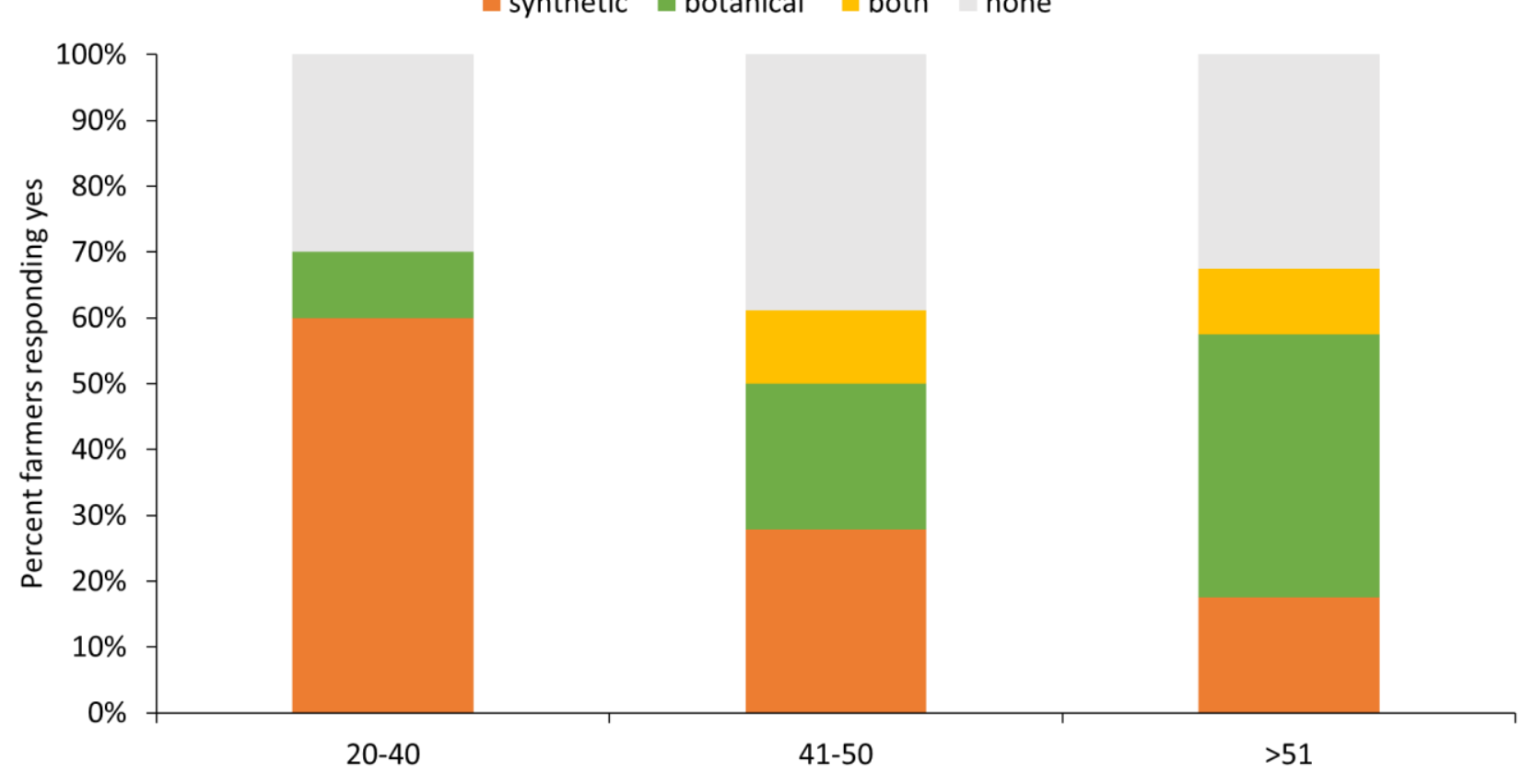

Figure 3. Relationship between the age of participants and their reported use of pesticidal plants and synthetic pesticides. Our results indicate that using synthetic pesticides decreased with increasing age. The opposite was observed for those using pesticidal plants extracts. 


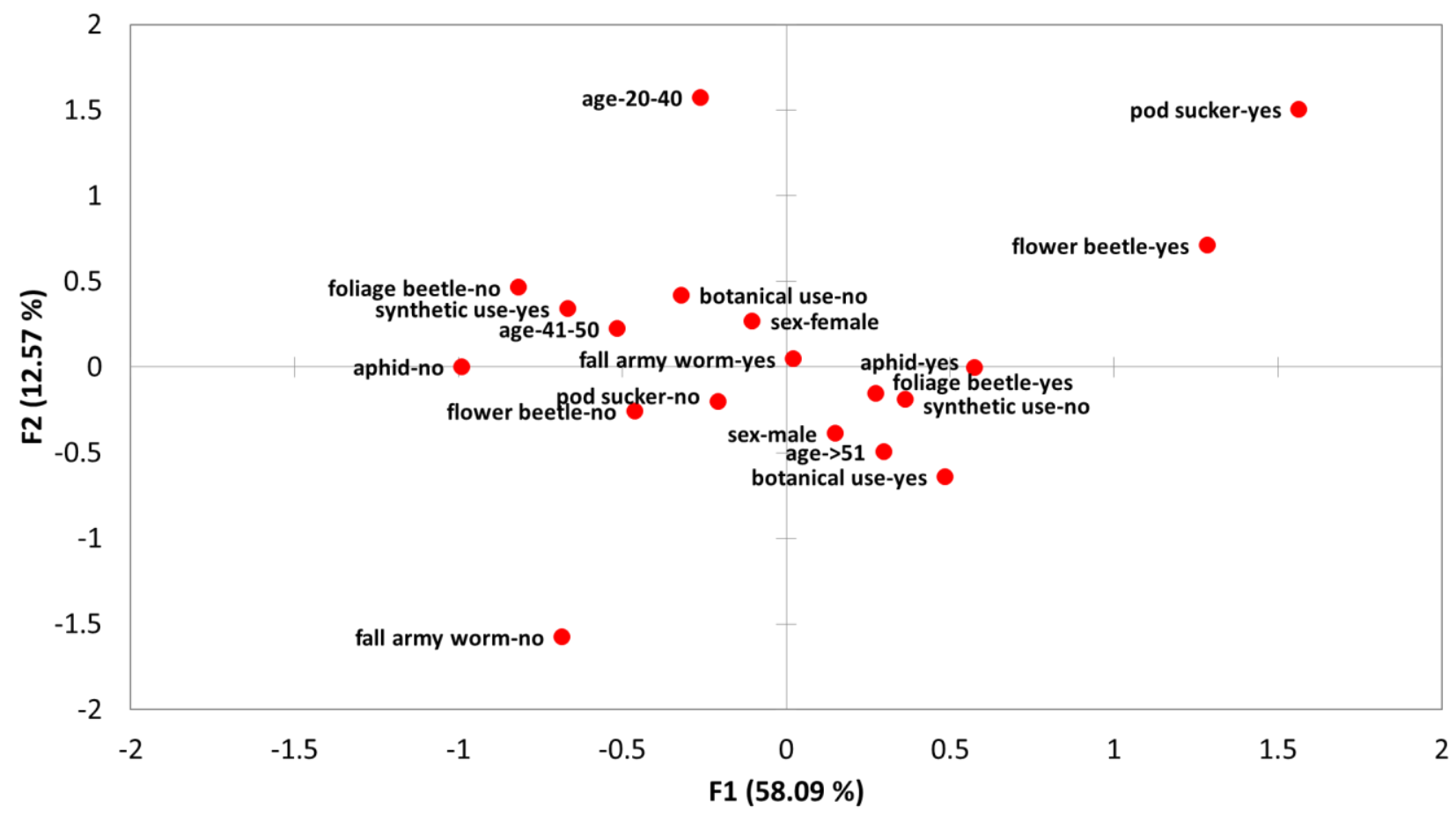

Figure 4. Multiple correspondence analysis where the first two dimensions (F1 and F2) can explain 70.6\% of the variance observed among variables. The variables include the age and gender of participants, together with their responses on pest control options and pest species presence with respect to common bean crop production.

\subsection{Participatory Cost-Benefit Analysis}

Benefits identified by each FGD from using pesticidal plants varied depending on the participants' experiences with agricultural pests and control practices (Table 3). Evaluation of the benefits of using pesticidal plants was performed with respect to other pest management practices, where the primary comparison was the use of synthetic pesticides, which has been perceived as the main pest control strategy in the area for several decades. FGD participants had a chance to discuss each benefit and give a score based on the importance of the benefit relative to their own experience. Benefits in this study implied the gains and the importance obtained from the technology. The benefits included experiences gained through participating in the project, and personal understanding of pesticidal plant uses.

Table 3. Elucidation of the costs, benefits, trade-off balance and future investments as discussed and scored by farmers.

\begin{tabular}{|c|c|c|c|c|c|c|c|c|c|c|}
\hline & Ranking & $\begin{array}{c}\text { Farmer } \\
\text { Group } 1 \\
\mathbf{N}=\mathbf{1 7}\end{array}$ & $\begin{array}{c}\text { Farmer } \\
\text { Group } 2 \\
\mathbf{N}=7\end{array}$ & $\begin{array}{c}\text { Farmer } \\
\text { Group } 3 \\
\mathbf{N}=10\end{array}$ & $\begin{array}{c}\text { Farmer } \\
\text { Group } 4 \\
\mathbf{N}=10\end{array}$ & $\begin{array}{c}\text { Farmer } \\
\text { Group } 5 \\
\mathrm{~N}=8\end{array}$ & $\begin{array}{c}\text { Farmer } \\
\text { Group } 6 \\
\mathbf{N}=4\end{array}$ & $\begin{array}{c}\text { Farmer } \\
\text { Group } 7 \\
N=6\end{array}$ & $\begin{array}{c}\text { Farmer } \\
\text { Group } 8 \\
\mathbf{N}=9\end{array}$ & $\begin{array}{c}\text { Farmer } \\
\text { Group } 9 \\
\mathbf{N}=10\end{array}$ \\
\hline \multirow{7}{*}{ Benefits } & 1 & Accessibility & Medicine & Health & Accessibility & Health & Health & $\begin{array}{c}\text { Pest } \\
\text { control }\end{array}$ & Health & Medicine \\
\hline & 2 & Health & $\begin{array}{c}\text { Plant } \\
\text { booster }\end{array}$ & Low cost & Low cost & Ecosystem & Ecosystem & Health & Low cost & Health \\
\hline & 3 & $\begin{array}{l}\text { Quality } \\
\text { crops }\end{array}$ & Accessibility & Accessibility & Health & Low cost & Low cost & Low cost & Ecosystem & $\begin{array}{l}\text { Pests } \\
\text { control }\end{array}$ \\
\hline & 4 & $\begin{array}{l}\text { Long } \\
\text { storage }\end{array}$ & Health & $\begin{array}{c}\text { Pest } \\
\text { control }\end{array}$ & Ecosystem & Accessibility & $\begin{array}{c}\text { Plant } \\
\text { booster }\end{array}$ & Accessibility & $\begin{array}{c}\text { Soil } \\
\text { fertility }\end{array}$ & Low cost \\
\hline & 5 & $\begin{array}{c}\text { Soil } \\
\text { fertility }\end{array}$ & $\begin{array}{c}\text { Soil } \\
\text { fertility }\end{array}$ & $\begin{array}{l}\text { Long } \\
\text { storage }\end{array}$ & Income & & Accessibility & Income & $\begin{array}{c}\text { Pest } \\
\text { control }\end{array}$ & Accessibility \\
\hline & 6 & Ecosystem & & $\begin{array}{c}\text { Soil } \\
\text { fertility }\end{array}$ & & & & $\begin{array}{l}\text { Long } \\
\text { storage }\end{array}$ & & Management \\
\hline & 7 & Income & & Income & & & & Medicine & & Ecosystem \\
\hline
\end{tabular}


Table 3. Cont.

\begin{tabular}{|c|c|c|c|c|c|c|c|c|c|c|}
\hline & Ranking & $\begin{array}{c}\text { Farmer } \\
\text { Group } 1 \\
\mathbf{N}=\mathbf{1 7}\end{array}$ & $\begin{array}{c}\text { Farmer } \\
\text { Group } 2 \\
N=7\end{array}$ & $\begin{array}{c}\text { Farmer } \\
\text { Group } 3 \\
\mathbf{N}=10\end{array}$ & $\begin{array}{c}\text { Farmer } \\
\text { Group } 4 \\
\mathrm{~N}=10\end{array}$ & $\begin{array}{c}\text { Farmer } \\
\text { Group } 5 \\
N=8\end{array}$ & $\begin{array}{c}\text { Farmer } \\
\text { Group } 6 \\
\mathrm{~N}=4\end{array}$ & $\begin{array}{c}\text { Farmer } \\
\text { Group } 7 \\
N=6\end{array}$ & $\begin{array}{c}\text { Farmer } \\
\text { Group } 8 \\
\mathbf{N}=9\end{array}$ & $\begin{array}{c}\text { Farmer } \\
\text { Group } 9 \\
\mathbf{N}=10\end{array}$ \\
\hline \multirow{6}{*}{ Costs } & 1 & $\begin{array}{l}\text { Short } \\
\text { storage }\end{array}$ & Tools & Drought & Awareness & Land size & Tools & Awareness & Drought & Awareness \\
\hline & 2 & Tools & Preparation & Tools & Preparation & Tools & Availability & Trust & Tools & $\begin{array}{l}\text { Farmer } \\
\text { team work }\end{array}$ \\
\hline & 3 & Preparation & Harvesting & Awareness & Tools & $\begin{array}{l}\text { Farmer } \\
\text { team work }\end{array}$ & Drought & Preparation & Land size & Tools \\
\hline & 4 & Distance & Distance & Preparation & Availability & $\begin{array}{l}\text { External } \\
\text { support }\end{array}$ & Land size & & Availability & Preparation \\
\hline & 5 & & & Availability & & Market & & & Poisonous & \\
\hline & 6 & & & Market & & Availability & & & Awareness & \\
\hline \multirow[t]{2}{*}{ Trade-offs } & & Positive & Positive & Positive & Positive & $\begin{array}{c}\text { Equal } \\
\text { balance }\end{array}$ & Positive & Positive & Positive & Positive \\
\hline & 1 & $\begin{array}{c}\text { Plants } \\
\text { cultivation }\end{array}$ & $\begin{array}{l}\text { Use wild } \\
\text { species }\end{array}$ & $\begin{array}{l}\text { Make } \\
\text { business }\end{array}$ & Education & Tools & $\begin{array}{c}\text { Make } \\
\text { business }\end{array}$ & Education & Education & Education \\
\hline \multirow{3}{*}{$\begin{array}{l}\text { Future in- } \\
\text { vestment }\end{array}$} & 2 & $\begin{array}{l}\text { Use wild } \\
\text { species }\end{array}$ & $\begin{array}{l}\text { Early } \\
\text { prepara- } \\
\text { tion }\end{array}$ & $\begin{array}{c}\text { Plants } \\
\text { cultivation }\end{array}$ & Tools & $\begin{array}{l}\text { External } \\
\text { support }\end{array}$ & Tools & Mobilization & Tools & $\begin{array}{c}\text { Plants } \\
\text { cultivation }\end{array}$ \\
\hline & 3 & Tools & $\begin{array}{c}\text { Plants } \\
\text { cultivation }\end{array}$ & Expertise & $\begin{array}{l}\text { Production } \\
\text { size }\end{array}$ & $\begin{array}{c}\text { Plants } \\
\text { cultivation }\end{array}$ & Mobilization & $\begin{array}{l}\text { Early } \\
\text { prepara- } \\
\text { tion }\end{array}$ & & Monitoring \\
\hline & 4 & & & & Experimenti & & & & & \\
\hline
\end{tabular}

Farmers reported that they perceived plant extracts to be less harmful to humans in comparison with synthetic pesticides. A health benefit was mentioned by all FGD groups and was ranked overall as the most important benefit. Farmers discussed various disorders that were perceived to be associated with poisons generally and agreed that using pesticidal plants did not result in such disorders. One participant reported that, "Plants do not affect the chest, so you do not have to drink milk after getting into contact compared with when you spray using synthetic pesticides". Plant availability was another mentioned benefit of using pesticidal plants, as farmers reported that it was easy to access the materials. The study area contains several wild pesticidal plant species in various locations, such as along roads, in field margins, in abandoned fields and in uncultivated areas. Some farmers reported that pesticidal plants were useful as a source of plant nutrients. One participant highlighted her experience of pesticidal plants on her garden: "When I used the plant materials, my beans were greener". Greenness, as observed by a farmer, was related to plant vigour, and previous research has shown that using pesticidal plants for pest control can also boost growth perhaps because the extracts act as a foliar fertiliser [10].

Costs in this study were the factors that inhibited the use of pesticidal plants and were elicited in comparison to more feasible pest control strategies used among the community members or imagined to be useful (Table 3). The most frequently mentioned cost was a lack of tools, encompassing the working equipment for harvesting, processing and application of plant extracts. Eight out of nine groups mentioned tools as a cost. Specifically, items such as masks, gloves, powered mechanical grinders, filtering cloths and drying areas, large volume tanks for extracts preparation and protective equipment were the most mentioned tools. Farmers stipulated that the manual preparation of plants was timeconsuming, particularly the manual pounding of leaves to create a powder, which requires much labour and is not very efficient, as not all plant fibres are ground into powder; very fine powder often blows away during the process. Farmers did recognise the grinding process was important to increase efficiency in extraction, and that access to powered grinding machines could resolve this issue. Other technical issues such as space to dry plant materials were reported-particularly being able to shade-dry materials to protect the compounds from breaking down when dried in the sun and trying to dry materials at times of high humidity, where poor drying could lead to moulds developing that could reduce efficacy of the plant materials. Other costs mentioned were the overall lengthy 
process of measuring and handling plant extracts, which is not as fast as using synthetic pesticides. One participant reported, "There is long time involved from going to collect plant materials, drying, grinding, soaking for a day and then filtering process"; and another farmer added, "This is different from the synthetic pesticides where you just go to the shops and buy a ready-made bottle of pesticides or a pack of dust material".

Awareness was highlighted as a cost by five FGDs and was related to the types of information offered by agricultural experts and knowledge from extension services. Farmers reported that extension officers focused mainly on the use of commercial synthetic inputs and suggested that local experts did not have pesticidal plant knowledge, and hence were unable to disseminate such knowledge to farmers. Participants mentioned that the government support system to farmers provided subsidies for synthetic pesticides and fertilizers but did not support farmers to market pesticidal plant raw materials and products. One farmer insisted that for any technology to be adopted, it has to contribute to the participants' means of income generation. The farmer said, "If we don't have a market we can leave the idea because why are shops selling chemicals and we cannot sell plant extracts?". Participants stressed that for any innovation to succeed, the presence of an income generation avenue needs to be upheld. Income generation is a means through which the technology would penetrate widely to communities. Unexpectedly, there were no costs mentioned related to pest management, even though pest control was central to the pesticidal plants' use.

The trade-off between costs and benefits was reached through discussing the cost and benefit scores. Participants weighed out the benefits and costs of using pesticidal plants and were able to tell whether the balance was positive, negative or equal. A positive balance implied that the benefits were more significant than the costs, and a negative balance implied that the costs were more significant than the benefits. Eight of the nine groups reached a consensus of a positive balance (Table 3).

The final components of the FDG involved discussion of contextual factors that could shift the cost-benefit balance in either direction and areas for future investments. The most important future interventions were considered to be (1) domestication of pesticidal plants to increase supply, (2) availability of tools for processing of the plant extracts, and (3) education about using them. Education in this study implied the need for knowledge shared through training, experimentation and farmer-to-farmer knowledge exchange. Participants viewed the FRN program as a sustainable example of education, farmer-tofarmer learning and knowledge exchange.

\section{Discussion}

Conventional cost-benefit analyses generally rely on data collected about financial inputs and resultant profits or losses to understand whether an activity makes economic sense, and more qualitative assessments of costs and benefits are not included [21]. Our recent work has shown that using this approach, the cost benefits of using pesticidal plants can be demonstrated [5,18]. However, here, we argue that social and environmental benefits and costs are not well-served through a purely monetary interpretation, particularly where activities are related to quality of life, agro-ecology and environmental sustainability [22]. Furthermore, a qualitative assessment is more likely to help identify constraints and opportunities; for example, the high labour inputs in the traditional processing of plant materials can be resolved through investment in improved drying and grinding facilities [23]. Likewise, improvement in health identified as a benefit would explain many specific benefits underlying health. While we might question the sized of some of these costs and benefits, they are what farmers notice and care about, thereby driving behavioural change.

Results from our survey confirm that pesticidal plants have been used by a minority of farmers in the region for decades, although with inadequate validation and reproducible methods. Local preparation and use of pesticidal plants is a common practice [24] that is known to have been practised several generations [25]. As has been highlighted by surveys elsewhere in Africa [26], the use of pesticidal plants tends to be highest amongst older 
farmers who have had the information passed down to them. Our study confirmed this and that younger generations of farmers are more reliant on commercial synthetic products; these farmers perceive synthetics to be quick and easy to use, while perhaps placing less importance on some of the environmental and safety costs known to be associated with synthetic products [27-29]. The adoption of synthetic pesticides was related to the influence of extension services. Farmers who received knowledge from extension services reported that they received advice mainly on synthetic pesticides and fertilizers and not any services that used natural products. However, farmers reported using synthetic chemicals as the most popular intervention, even when no expert directed them to do so, probably due to generally greater awareness, so their use cannot simply be a consequence of extension service interventions. That said, [30] reported that extension services have a significant influence on the adoption of technologies because they directly communicate agronomic practices to farmers. From this survey, we identify that extension service knowledge related to using pesticidal plants must be strengthened to increase adoption of the technology.

Although survey questions about insect pest problems were asked independently from pest control practices, there was a clear association between farmers reporting pest issues and whether they used synthetic or pesticidal plant pest control. Farmers who reported no problems with key pest species generally used synthetic pesticides, whereas those using pesticidal plants also reported pests. This strong bias suggests that farmers perceived their lack of/presence of pest problems to be a function of their pest control actions, as opposed to generally reporting they have problems with pests. In addition, there is good evidence that pesticidal plants do not result in the levels of insect control that are equivalent to correctly used synthetics, although this does not lead to lower yields in crops treated with pesticidal plants; and the impact on beneficial insects is much reduced [10,19].

From the FGDs, farmers highlighted costs, benefits and the challenges and opportunities regarding increasing the use of pesticidal plants. Farmers reported that tools for harvesting, processing and applying plant extracts were inadequate. These elaborated that findings resonate well with the cost-benefit analysis conducted by Baidoo and Mochiah [31], who reported labour as a cost hindering the use of pesticidal plants. Other studies, such as a report from Ngbede et al. [32], showed that the use of pesticidal plants in the control of cabbage had lower costs than the use of synthetic pesticides. Dougoud et al. [24] acknowledged that pesticidal plants were a better alternative to synthetic pesticides, although challenges such as processing methods, variable active ingredients and lower duration of efficacy existed.

Benefits of using pesticidal plants included improvements to human health (in comparison to synthetic pesticide use), readily accessible materials and safety to environment. These benefits are also reported widely in the literature $[3,10,11,19,33,34]$. These findings coincide with farmers' information from the study area that plants used as pesticides can often also be used as medicines. Many are consumed to treat various ailments. Across Africa, there is growing evidence that farmers are not using synthetic pesticides safely, as many do not wear adequate personal protection when they are spraying such chemicals, and often use chemicals that are inappropriate for their crops at excessive dosages or adulterated mixtures. Many high-risk chemical pesticides continue to be used in Africa [35], and recent studies suggest that farmers are being exposed to dangerous levels of several pesticides, including long-banned legacy pesticides such as endosulphan [36] and DDT [37]. This raises the need for better awareness and education, but also highlights the importance of promoting lower risk pesticides such as pesticidal plant extracts. The lower risks of using plant extracts were explained by farmers, who reported that it was not necessary to take antidotes after spraying plant extracts to treat chest pain, an effect linked with effects acquired from spraying synthetic pesticides whereby drinking milk is often used as an antidote [38].

Local availability of plant materials was reported in this study as a critical benefit, because many pesticidal plant species can be obtained from the farmers' premises in adequate quantities. Pesticidal plants such as Tithonia diversifolia and Lantana camara are 
invasive weeds that spread quickly, and the use of such plant material as pesticides can assist in suppressing their spread. Other pesticidal plants such as Tephrosia vogelii can be propagated easily to provide highly effective pesticidal plant extracts $[10,19]$. Farmers reported bean crops were greener when treated with pesticidal plant extracts. It has been confirmed that pesticidal plant extracts can also act as foliar fertilisers [14]. Soil improvement properties can also be observed when growing and using species such as $T$. vogelii and T. diversifolia $[39,40]$.

Carrying out this participatory cost-benefit analysis enabled farmers to assess the trade-offs in using pesticidal plants, giving weight to farmers' perceptions that potentially reflect a willingness to adopt the technology. In support of our findings, Kaphle and Bastakoti, [41] showed that $80 \%$ of farmers growing vegetables in parts of Nepal could be motivated towards using pesticidal plants through farmer involvement in participatory research trials. Critical suggestions from farmers are essential to increasing adoption of farming innovations. Research has shown that top-down recommendations to farmers may be inappropriate and less effective [42]. Practical learning regarding the tools and processing of pesticidal plants could be further augmented through other innovations, such as video-mediated learning [5].

\section{Conclusions}

This study has provided some evidence on how a qualitative cost-benefit analysis can contribute to eliciting critical factors required to increase uptake of sustainable pest management technologies. The study has identified (1) key costs, including a lack of working tools, awareness by farmers of the benefits of using pesticidal plants and the hardships in the preparation process; (2) key benefits, including health benefits and local availability of plants materials; (3) a positive trade-off balance; and (4) future requirements for better uptake, including tools and awareness of the processes involved in using pesticidal plants. Farmers' involvement in analysing costs and benefits can lead to context-based agro-ecological methods that result in more impactful and sustainable research. The analysis suggests that increased efforts to support agro-ecological technologies through enabling government policies could dramatically improve smallholder livelihoods.

Supplementary Materials: The following are available online at https://www.mdpi.com/article/10 .3390 /agriculture11101007/s1. S1: Individual questionnaire survey. S2 Focus group discussion topics.

Author Contributions: Conceptualization, A.G.M., P.C.S., S.R.B., P.A.N. and R.C.; methodology., A.G.M., formal analysis, A.G.M., R.C., S.R.B.; investigation, A.G.M., resources, S.R.B.; data curation, A.G.M. and R.C.; writing—original draft preparation, A.G.M.; writing—review and editing, A.G.M., R.C., P.A.N., P.C.S. and S.R.B.; visualization, S.R.B.; supervision, P.A.N., S.R.B. and P.C.S.; project administration, S.R.B.; funding acquisition, S.R.B. and P.A.N. All authors have read and agreed to the published version of the manuscript.

Funding: This research was funded by grants from the McKnight foundation to SRB Grant No: 17-070 an d 20-034.

Institutional Review Board Statement: The study was conducted according to the Nelson Mandela African Institution of Science and Technology, School of Life Sciences and Bioengineering's approval for $\mathrm{PhD}$ research study. The approval was granted under the $\mathrm{PhD}$ registration P191/T.16, in January 2028. An endorsement was given by an authorization letter by the District Executive Director of the Hai district council where the study was conducted.

Informed Consent Statement: Informed consent was obtained from all subjects involved in the study.

Conflicts of Interest: The authors declare that the research was conducted in the absence of any commercial or financial relationships that could be construed as a potential conflict of interest. 


\section{References}

1. Isman, M.B. Botanical insecticides: For richer, for poorer. Pest Manag. Sci. 2008, 64, 8-11. [CrossRef]

2. Isman, M.B. Botanical Insecticides in the Twenty-First Century—Fulfilling Their Promise? Annu. Rev. Entomol. 2020, 65, 233-249. [CrossRef] [PubMed]

3. Stevenson, P.C.; Isman, M.B.; Belmain, S.R. Pesticidal plants in Africa: A global vision of new biological control products from local uses. Ind. Crop. Prod. 2017, 110, 2-9. [CrossRef]

4. Sola, P.; Mvumi, B.M.; Ogendo, J.O.; Mponda, O.; Kamanula, J.F.; Nyirenda, S.P.; Belmain, S.R.; Stevenson, P.C. Botanical pesticide production, trade and regulatory mechanisms in sub-Saharan Africa: Making a case for plant-based pesticidal products. Food Secur. 2014, 6, 369-384. [CrossRef]

5. Amoabeng, B.W.; Gurr, G.M.; Gitau, C.W.; Stevenson, P.C. Cost: Benefit analysis of botanical insecticide use in cabbage: Implications for smallholder farmers in developing countries. Crop Prot. 2014, 57, 71-76. [CrossRef]

6. Ndakidemi, P.A.; Dakora, F.D.; Nkonya, E.M.; Ringo, D.; Mansoor, H. Yield and economic benefits of common bean (Phaseolus vulgaris) and soybean (Glycine max) inoculation in northern Tanzania. Aust. J. Exp. Agric. 2006, 46, 571-577. [CrossRef]

7. Murphy, K.E.; Simon, S.J. Using cost benefit analysis for enterprise resource planning project evaluation: A case for including intangibles. In Enterprise Resource Planning: Global Opportunities and Challenges; IGI Global: Hershey, PA, USA, 2002; pp. 245-266.

8. Isman, M.; Grieneisen, M. Botanical insecticide research: Many publications, limited useful data. Trends Plant Sci. 2014, 19, 140-145. [CrossRef]

9. Campos, E.V.R.; Proença, P.L.F.; Oliveira, J.L.; Bakshi, M.; Abhilash, P.C.; Fraceto, L.F. Use of botanical insecticides for sustainable agriculture: Future perspectives. Ecol. Indic. 2018, 105, 483-495. [CrossRef]

10. Tembo, Y.; Mkindi, A.G.; Mkenda, P.A.; Mpumi, N.; Mwanauta, R.; Stevenson, P.C.; Ndakidemi, P.A.; Belmain, S.R. Pesticidal Plant Extracts Improve Yield and Reduce Insect Pests on Legume Crops Without Harming Beneficial Arthropods. Front. Plant Sci. 2018, 9, 1425. [CrossRef]

11. Amoabeng, B.W.; Johnson, A.C.; Gurr, G.M. Natural enemy enhancement and botanical insecticide source: A review of dual use companion plants. Appl. Entomol. Zool. 2019, 54, 1-19. [CrossRef]

12. Stevenson, P.C.; Kite, G.C.; Lewis, G.P.; Forest, F.; Nyirenda, S.P.; Belmain, S.R.; Sileshi, G.W.; Veitch, N.C. Distinct chemotypes of Tephrosia vogelii and implications for their use in pest control and soil enrichment. Phytochemistry 2012, 78, 135-146. [CrossRef]

13. Mafongoya, P.L.; Kuntashula, E. Participatory evaluation of Tephrosia species and provenances for soil fertility improvement and other uses using farmer criteria in Eastern Zambia. Exp. Agric. 2005, 41, 69-80. [CrossRef]

14. Mkindi, A.G.; Tembo, Y.L.B.; Mbega, E.R.; Smith, A.K.; Farrell, I.W.; Ndakidemi, P.A.; Stevenson, P.C.; Belmain, S.R. Extracts of Common Pesticidal Plants Increase Plant Growth and Yield in Common Bean Plants. Plants 2020, 9, 149. [CrossRef]

15. Arlauskiene, A.; Jablonskyte-Rasce, D.; Slepetiene, A. Effect of legume and legume-festulolium mixture and their mulches on cereal yield and soil quality in organic farming. Arch. Agron. Soil Sci. 2020, 66, 1058-1073. [CrossRef]

16. Nyende, P.; Delve, R.J. Farmer participatory evaluation of legume cover crop and biomass transfer technologies for soil fertility improvement using farmer criteria, preference ranking and logit regression analysis. Exp. Agric. 2004, 40, 77-88. [CrossRef]

17. Grzywacz, D.; Stevenson, P.C.; Mushobozi, W.L.; Belmain, S.R.; Wilson, K. The use of indigenous ecological resources for pest control in Africa. Food Secur. 2014, 6, 71-86. [CrossRef]

18. Mkenda, P.; Mwanauta, R.; Stevenson, P.C.; Ndakidemi, P.; Mtei, K.; Belmain, S.R. Extracts from field margin weeds provide economically viable and environmentally benign pest control compared to synthetic pesticides. PLoS ONE 2015, 10, e0143530. [CrossRef] [PubMed]

19. Mkindi, A.; Mpumi, N.; Tembo, Y.; Stevenson, P.C.; Ndakidemi, P.A.; Mtei, K.; Machunda, R.; Belmain, S.R. Invasive weeds with pesticidal properties as potential new crops. Ind. Crop. Prod. 2017, 110, 113-122. [CrossRef]

20. Nelson, R.; Coe, R.; Haussmann, B.I.G. Farmer research networks as a strategy for matching diverse options and contexts in smallholder agriculture. Exp. Agric. 2019, 55, 125-144. [CrossRef]

21. Pearce, D.; Atkinson, G.; Mourato, S. Cost-Benefit Analysis and the Environment; OECD: Paris, France, 2006 ; ISBN 9789264010048.

22. Cooke, I.R.; Queenborough, S.A.; Mattison, E.H.A.; Bailey, A.P.; Sandars, D.L.; Graves, A.R.; Morris, J.; Atkinson, P.W.; Trawick, P.; Freckleton, R.P.; et al. Integrating socio-economics and ecology: A taxonomy of quantitative methods and a review of their use in agro-ecology. J. Appl. Ecol. 2009, 46, 269-277. [CrossRef]

23. Van Berkel, D.B.; Carvalho-Ribeiro, S.; Verburg, P.H.; Lovett, A. Identifying assets and constraints for rural development with qualitative scenarios: A case study of Castro Laboreiro, Portugal. Landsc. Urban Plan. 2011, 102, 127-141. [CrossRef]

24. Dougoud, J.; Toepfer, S.; Bateman, M.; Jenner, W.H. Efficacy of homemade botanical insecticides based on traditional knowledge. A review. Agron. Sustain. Dev. 2019, 39, 37. [CrossRef]

25. Pavela, R. History, presence and perspective of using plant extracts as commercial botanical insecticides and farm products for protection against insects-A review. Plant Prot. Sci. 2016, 52, 229-241.

26. Cobbinah, J.R.; Moss, C.; Golob, P.; Belmain, S.R. Conducting Ethnobotanical Surveys: An Example from Ghana on Plants Used for the Protection of Stored Cereals and Pulses; Natural Resources Institute: Chatham, UK, 1999.

27. Sapbamrer, R.; Thammachai, A. Factors affecting use of personal protective equipment and pesticide safety practices: A systematic review. Environ. Res. 2020, 185, 109444. [CrossRef] [PubMed]

28. Sankoh, A.I.; Whittle, R.; Semple, K.T.; Jones, K.C.; Sweetman, A.J. An assessment of the impacts of pesticide use on the environment and health of rice farmers in Sierra Leone. Environ. Int. 2016, 94, 458-466. [CrossRef] [PubMed] 
29. Williamson, S.; Ball, A.; Pretty, J. Trends in pesticide use and drivers for safer pest management in four African countries. Crop Prot. 2008, 27, 1327-1334. [CrossRef]

30. Abatania, L.N.; Gyasi, K.O.; Salifu, A.B.; Coulibaly, O.N.; Razak, A. Factors affecting the adoption of botanical extracts as pesticides in cowpea production in northern Ghana. Ghana J. Agric. Sci. 2009, 43, 9-15.

31. Baidoo, P.K.; Mochiah, M.B. Comparing the Effectiveness of Garlic (Allium sativum L.) and Hot Pepper (Capsicum frutescens L.) in the Management of the Major Pests of Cabbage Brassica oleracea (L.). Sustain. Agric. Res. 2016, 5, 83. [CrossRef]

32. Ngbede, S.O.; Nwanguma, E.I.; Onyegbule, U.N.; Okpara, S.C.; Uwalaka, O. Cost: Benefit Analysis of Botanical Insecticide Use in Watermelon Production in Okigwe, Southeastern Nigeria. Int. J. Sci. Technol. Res. 2014, 3, 16-20.

33. Mkenda, P.P.A.; Stevenson, P.C.P.; Ndakidemi, P.; Farman, D.I.; Belmain, S.R. Contact and fumigant toxicity of five pesticidal plants against Callosobruchus maculatus (Coleoptera: Chrysomelidae) in stored cowpea (Vigna unguiculata). Int. J. Trop. Insect Sci. 2015, 35, 172-184. [CrossRef]

34. Jepson, P.C.; Murray, K.; Bach, O.; Bonilla, M.A.; Neumeister, L. Selection of pesticides to reduce human and environmental health risks: A global guideline and minimum pesticides list. Lancet Planet. Health 2020, 4, e56-e63. [CrossRef]

35. Donald, C.E.; Scott, R.P.; Blaustein, K.L.; Halbleib, M.L.; Sarr, M.; Jepson, P.C.; Anderson, K.A. Silicone wristbands detect individuals' pesticide exposures in West Africa. R. Soc. Open Sci. 2016, 3, 160433. [CrossRef] [PubMed]

36. Menezes, R.G.; Qadir, T.F.; Moin, A.; Fatima, H.; Hussain, S.A.; Madadin, M.; Senthilkumaran, S. Endosulfan poisoning: An overview. J. Forensic Leg. Med. 2017, 51, 27-33. [CrossRef] [PubMed]

37. Lekei, E.E.; Ngowi, A.V.; London, L. Farmers' knowledge, practices and injuries associated with pesticide exposure in rural farming villages in Tanzania. BMC Public Health 2014, 14, 389. [CrossRef] [PubMed]

38. Munthali, M.G.; Gachene, C.K.K.; Sileshi, G.W.; Karanja, N.K. Amendment of Tephrosia Improved Fallows with Inorganic Fertilizers Improves Soil Chemical Properties, N Uptake, and Maize Yield in Malawi. Int. J. Agron. 2014, 2014, 902820. [CrossRef]

39. Jama, B.; Palm, C.A.; Buresh, R.J.; Niang, A.; Gachengo, C.; Nziguheba, G.; Amadalo, B. Tithonia diversifolia as a green manure for soil fertility improvement in western Kenya: A review. Agrofor. Syst. 2000, 49, 201-221. [CrossRef]

40. Kaphle, M.; Bastakoti, N. A case study on botanical pesticides and vermicompost fertilizer for adopting new agricultural practice by farmers. J. Agric. Environ. 2018, 17, 56-64. [CrossRef]

41. Litsinger, J.A.; Libetario, E.M.; Canapi, B.L. Eliciting farmer knowledge, attitudes, and practices in the development of integrated pest management programs for rice in Asia. In Integrated Pest Management; Springer: Dordrecht, The Netherlands, 2009; Volume 2, pp. 119-273, ISBN 9781402089909.

42. Chowdhury, A.; Odame, H.H.; Thompson, S.; Hauser, M. International Journal of Agricultural Sustainability Enhancing farmers' capacity for botanical pesticide innovation through video-mediated learning in Bangladesh. Int. J. Agric. Sustain. 2015, 13, 326-349. [CrossRef] 